\title{
SILENT EVOLUTION
}

\author{
It's only a matter of time.
}

BY C. N. SIMMS

$\mathrm{T}$ he moan echoes around the control chamber with resonant longing. It is louder this time, and the tremoring of the alloy walls makes the sound hard to ignore.

"It's getting hungry," the tulip-red gentian says, stating the obvious.

The smaller co-pilot vibrates once in boredom and its engorged eye drifts to the bank of screens. It waves its three-fingered protuberance vaguely at the visualization of the huge superorganism surrounding the control shell. Only about one-tenth of the seething mass is shaded. "It's running low on fuel. How many have we got left?"

The larger gentian cranes its head awkwardly towards the rack of entubed capttives. Paired eyes stare blankly ahead, unaware of the gentian's intentions. "Seven," it says, but the trapped beings can't hear the word. If they were awake, they would see only what is directly in front of them, and if they could hear anything, it would be no more than the whispered ghosts of shouts.

The other gentian does a brief calculation on a dashboard of glowing keys. Both creatures nod in relief. Plenty left.

"How about we..." They have the idea together, but it is the larger gentian that utters the suggestion.

"No."

"But we'll have one or two to spare."

"No. They all have to be accounted for."

"Just a small one... Maybe this one will be a better example."

As the two gentians consider the temptation, their skins undulate and shimmer with the sunset hues of an evening ocean. Intricate patterns swirl in unhideable reflections of their thoughts. So far, most of the defrosted specimens had been disappointing, seeming to fearfully blurt out nonsensical sentences rather than being the individual fonts of theory and wisdom that the gentians had imagined from the contents of the time capsules.

"I know you're tempted too. You can't hide it. None of us can. They fascinate me constantly," trumpets the larger gentian.

"Still?" snaps the other, youthfully lighter.

"Yes, still. The very need they feel to be heard. The need to place their writings and messages in capsules and send them into

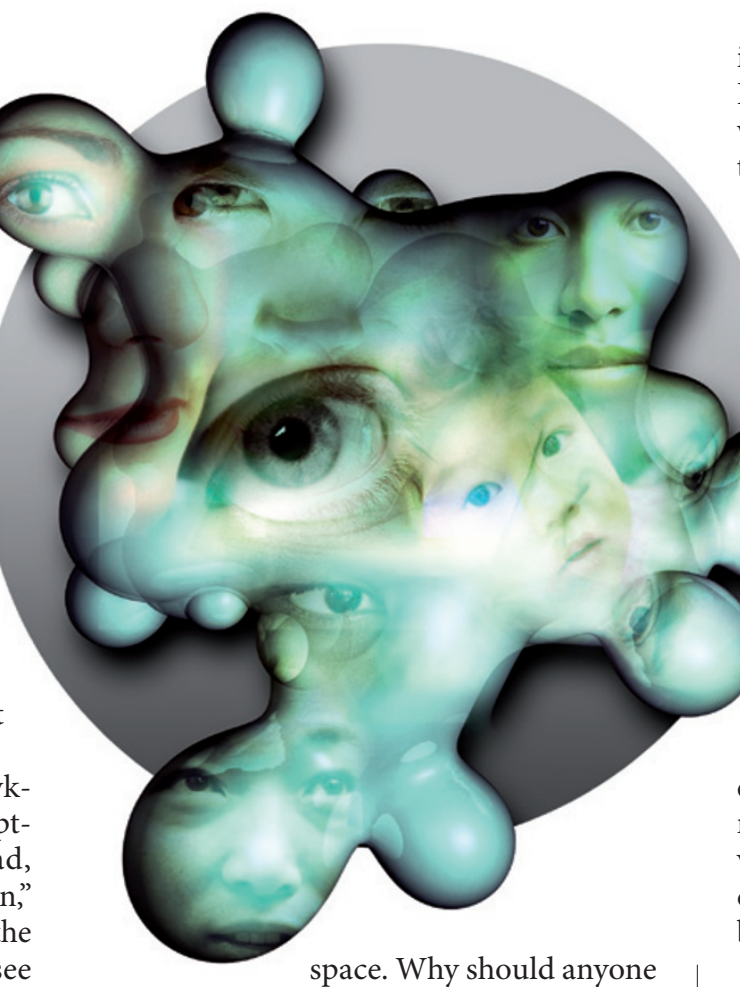

space. Why should anyone care? Why would they send cryogenically frozen people into the darkness?"

"It's because they aren't like us. They fantasize. They hope."

"Doesn't it make you wonder if we too could be like that?"

"Not really."

"You've got no soul," the larger gentian mutters.

"I don't see how the existence of an intangible existential and immortal spirit can be brought into question by a lack of interest in a race of inferior life forms."

"Et tu, Brute?"

"You're withdrawing. You realize that don't you? Your skin is thickening. I can hardly see what you're thinking any more. The more you study their texts, the more you are losing your sense of self. Your sense of being one of us. Of being one with us."

"One could argue that is not a sense of self per se."

"One could argue a lot of things. But as your favourite human wrote, 'men of few words are the best men."'

"You read him too!" The larger creature's

$\rightarrow$ NATURE.COM

Follow Futures on

Facebook at:

go.nature.com/mtoodm pellucid body ripples as amusement causes the jelly-like flesh to shake. As the movement subsides, its features reset in an approximation of seriousness. "But I am a gentian, not a man." It pauses and waves its protuberance for emphasis. "Still, there is so much in their work that is not like our thoughts. We think, we say. Or we say and then think. It makes little difference because we all know what the others mean as they speak. But humans cannot read minds. They cannot see the thoughts painted in the swirls of our skin. They have to be precise to convey their meaning, and in that precision there is art. Art - it's an unknown quantity to us. What need have we to see the perception of another when we already know their perception, for indeed it is our own?"

The younger gentian fixes its single eye on its companion. As ever there is no need for words. But as ever the thoughts are vocalized anyway. "Shut up," it says in a slow, drawl. "And throw another shrimp on the barbie."

For a moment the pigments under the skin of the older gentian whorl in an aggressive swarm, but then they are gone and it leans forwards and presses a button. With a dull whump, one of the cryogenically frozen humans is ejected through the floor. Instantly the metal reseals, maintaining the cell's atmosphere. The fuel indicator creeps upwards. The other humans can't see what has happened. None of them can hear the satisfied rumbling of the superorganism cradling the small ship. None of them even knows that there are others next to them.

"I wonder what human tastes like to a worldeater?" the smaller gentian muses.

"Better than a small moon, but less substantial. I don't care. As long as it stays full and can't eat through the walls of the control cell."

As the gentians continue to ponder thawing out a human, an eldritch moan courses from the cells of the worldeater around them. A single drop of digestive fluid plummets to the floor of the control capsule. Its falling is the tolling of a bell. With a fizz it begins to eat into the floor. The gentians wail to their faraway kin, but it is too late.

The worldeaters have evolved.

C N. Simms is a subeditor at Nature. As far as most worldeaters are concerned, he probably wouldn't taste as good as a freerange human. 